\title{
Impact of Intellectual Capital on Performance in Audit Institutes
}

\author{
Hossein Gazor (Corresponding author)
}

Department of Management \& Accounting

Allameh Tabataba'ee University, Tehran, Iran

Tel: 98-912-435-4291_E-mail: hosseingazor@yahoo.com

\author{
Farhad Kohkan \\ Department of Accounting, University of Science and Culture, Iran \\ E-mail: kohkan_farhad59@yahoo.com \\ Amene Kiarazm, \\ Department of Accounting, University of Science and Culture, Iran \\ E-mail: Ameneh.kiarazm@yahoo.com
}

Hashem Rastegari

Department of Management \& Accounting

Allameh Tabataba'ee University, Tehran, Iran

E-mail: Rastegari.hashem@gmail.com

Received: Nov. 13, 2012 Accepted: December 26, 2012 Published: June 1, 2013

doi:10.5296/ajfa.v5i1.2682ＵRL: http://dx.doi.org/10.5296/ajfa.v5i1.2682

\begin{abstract}
Intellectual capital is a momentous asset of today organizations by which they can create competitive advantages. In this paper, we attempt to investigate relationships between dimensions of intellectual capital and organization performance by means of a conceptual model. For testing model, we used path analysis with Lisrel. Study population was selected
\end{abstract}




\section{Macrothink

from accountants of accounting and audit institutes. Findings show that human capital plays a vital role in organisation performance.

Keywords: Human capital, Structural capital, Relational capital, Organizational performance 


\section{Introduction}

Intellectual capital is changing into a momentous issue for a firm's long-term profit and performance within the knowledge-based economy as a lot of corporations determine their core competence as invisible assets instead of visible assets. Nonaka and Takeuchi (1995) mentioned that future society could be a knowledge-based society during which knowledge storage and application are the premise of economic growth and accumulated capital. Because as Gazor et al. (2012) mentioned, knowledge is a firm's most valuable resource because it embodies intangible assets, routines, and creative processes. The concept of intellectual capital arises in varied disciplines. as an example, accountants have an interest in the way to measure it on the balance sheet; info technologists need to codify it in systems; sociologists need to balance power with it; psychologists need to develop minds due to it; human resource managers need to calculate a come on it; and coaching and development officers need to create positive that they will build it (Choo and Bontis, 2002; VII). This indicates that intellectual capital have many facet in scientific literatures.

Therefore, it is raised many questions about managing intellectual capital to obtain and maintain competitive advantages. Many of these researchers are interested in answering two questions: (1) what causes firms to be worth so much more than their book value, and (2) what specifically is in this intangible asset. Stewart (1997) defines intellectual capital as the intellectual material that has been formalized, captured, and leveraged to create wealth by producing a higher valued asset. Following the work of Bontis (1996a, 1988), Roos et al. (1998), Stewart (1991,1994,1997), Sveiby (1997), Edvinsson and Malone (1997), Saint-Onge (1996), Sullivan and Edvinsson (1996), and Edvinsson and Sullivan (1996), among others, intellectual capital is defined as encompassing (a) human capital, (b) structural capital, and (c) relational capital. These subphenomena encompass the intelligence found in human beings, organizational routines, and network relationships, respectively. We will explain these in coming sections in more detailed.

\section{Literature review}

\subsection{Intellectual capital definition}

Intellectual capital, a term initial introduced by economist John Kenneth Galbraith in 1969, refers to the distinction between an organization's market value and book value. Given the growing gap between the market and book values of firms, investigation into how to measure firms' intellectual capital and whether capital market is efficient with intellectual capital has been drawing broad research interest (Chen et al., 2005).

Several researchers have come back to treat intellectual capital as a firm's primary suggests that of creating competitive advantage. The abstract and dynamic nature of intellectual capital makes it troublesome for students to outline (Hsu and Fang, 2009). Guthrie (2001) considered intellectual capital and intellectual assets or intangible assets as synonyms. Some authors indicate that intellectual capital is the product of dynamic business operation processes, and is rigidly linked to knowledge management or organizational learning (Stewart, 1997; Roos, et al, 1998). Also accumulating intellectual capital is vital resources to create and maintain 


\section{Macrothink}

competitive advantage (Kaplan and Norton, 1992; Edvinsson and Sullivan, 1996; Edvinsson and Malone, 1997; McElroy, 2002).

\subsection{Intellectual capital classification}

Adopting Kogut and Zander's (1992) perspective on higher order organizing principles, figure 1 proposes a conceptualization of intellectual capital. Intellectual capital is a second-order multidimensional construct. Its three subdomains include (1) human capital - the tacit knowledge embedded in the people's minds, (2) structural capital - the organizational routines of the business, and (3) relational capital-the knowledge embedded in the relationships established with the outside environment (Edvinsson and Sullivan 1996).

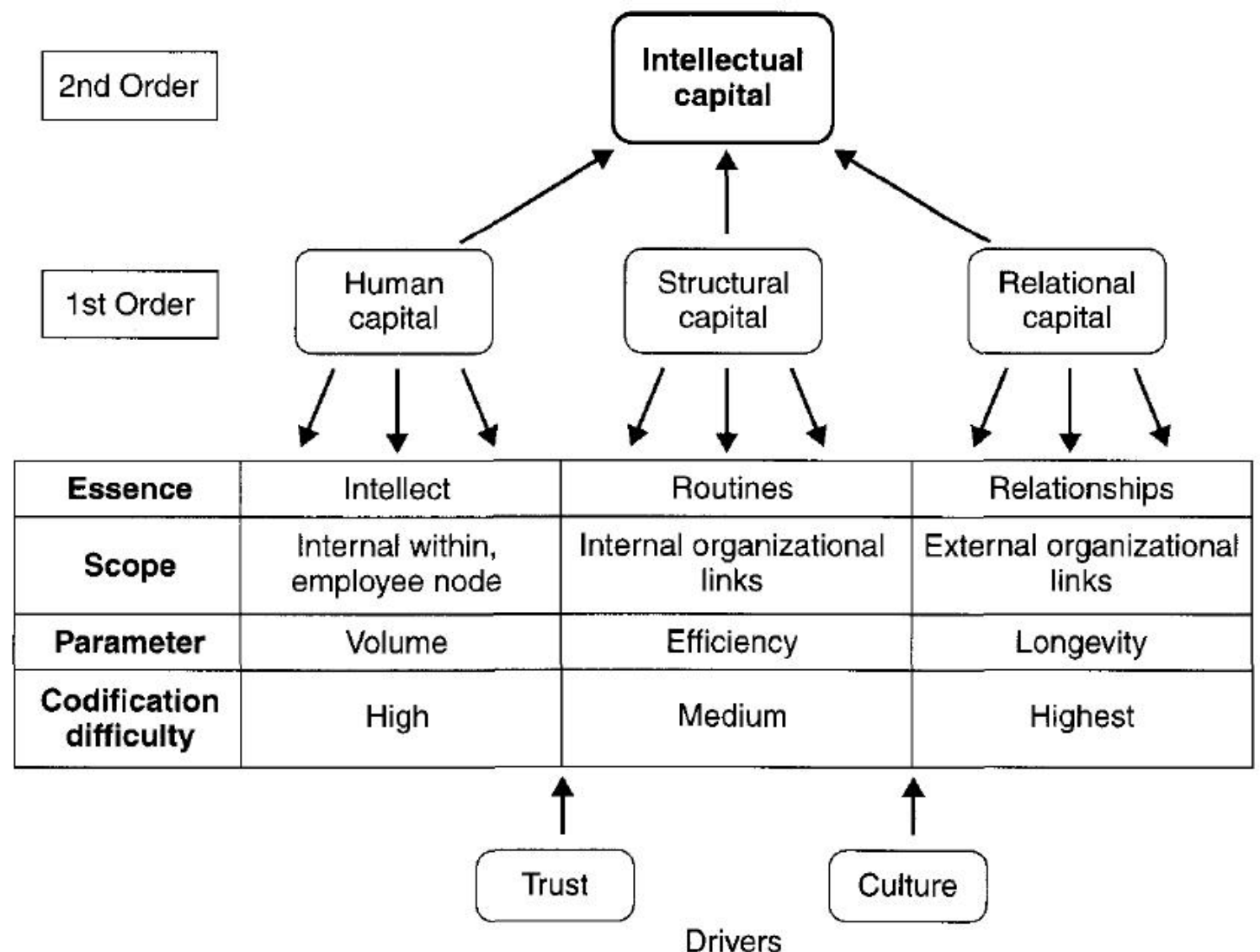

Figure 1. Conceptualization of intellectual capital (Source: Bontis, 2002; 629).

Roos et al. (1998) observe the excellence between intellectual capital and organizational information as follows: "While knowledge may be a part of intellectual capital, intellectual capital is far quite simply knowledge. Brands and emblems additionally because the management of relations with external parties (trade distributors, allies, customers, native communities, stakeholders generally and therefore the like) are all dimensions of price creation”, (p. 24). The strategic management of intellectual capital cares not solely with the identification and measurements of stocks of organizational knowledge, however additionally 
with the management and alignment of knowledge flow across organizational levels so as to boost performance.

\subsection{Human capital}

Human capital is a function of the competence, intellectual agility, and attitudes of the organization's members. Human capital represents the human factor in the organization: the combined intelligence, skills, expertise, and knowledge that give the organization its distinctive character. The human in the organization are those that are capable of learning, changing, innovating, value adding, and providing the creative thrust that can ensure the long-run survival of the organization if properly motivated. As per Lynn's (1998) overview of Human resource accounting, since Hermanson's classic study in 1964, the topic of how to and whether to value human assets has been debated by accountants and human resource theorists. Indeed, the arguments for and against human resource accounting are especially pertinent to the valuation of intellectual assets in the new economy since they involve essentially the same issues. Point A in figure 2 represents the core of human capital. Multiple nodes (human capital units) attempt to align themselves in some form of recognizable pattern so that intellectual capital becomes more readily interpretable. This point represents the lowest level of difficulty for development as well as the lowest level of externality from the core of the organization. Nelson and Winter (1982) analyzed an organization's capabilities. They noted that an individual's skills are composed of subelements that become coordinated in a smooth execution of the overall performance, impressive in its speed and accuracy, with conscious deliberation being confined to matters of overall importance.

Research by Hurwitz et al. (2002) shows that a firm's profit derived primarily from human capital. A firm hiring skilled employees and experienced managers will have higher performance because its manpower can bring skills and capabilities into full play (Rhyne et al, 2002). Prominent managers with knowledge and vision help organizations fast respond to the market in highly dynamic environment. Appreciate to managers, organizations may lead the market, and improve their market value and share. In addition, Dakhli and De Clercq (2004) show that there is a positive relationship between human capital and innovation. Human capital collection determines teamwork performance and the better the employee quality, the higher the innovation performance. Based on these findings, following hypothesis is developed:

H1: Human capital affects organizational performance positively. 


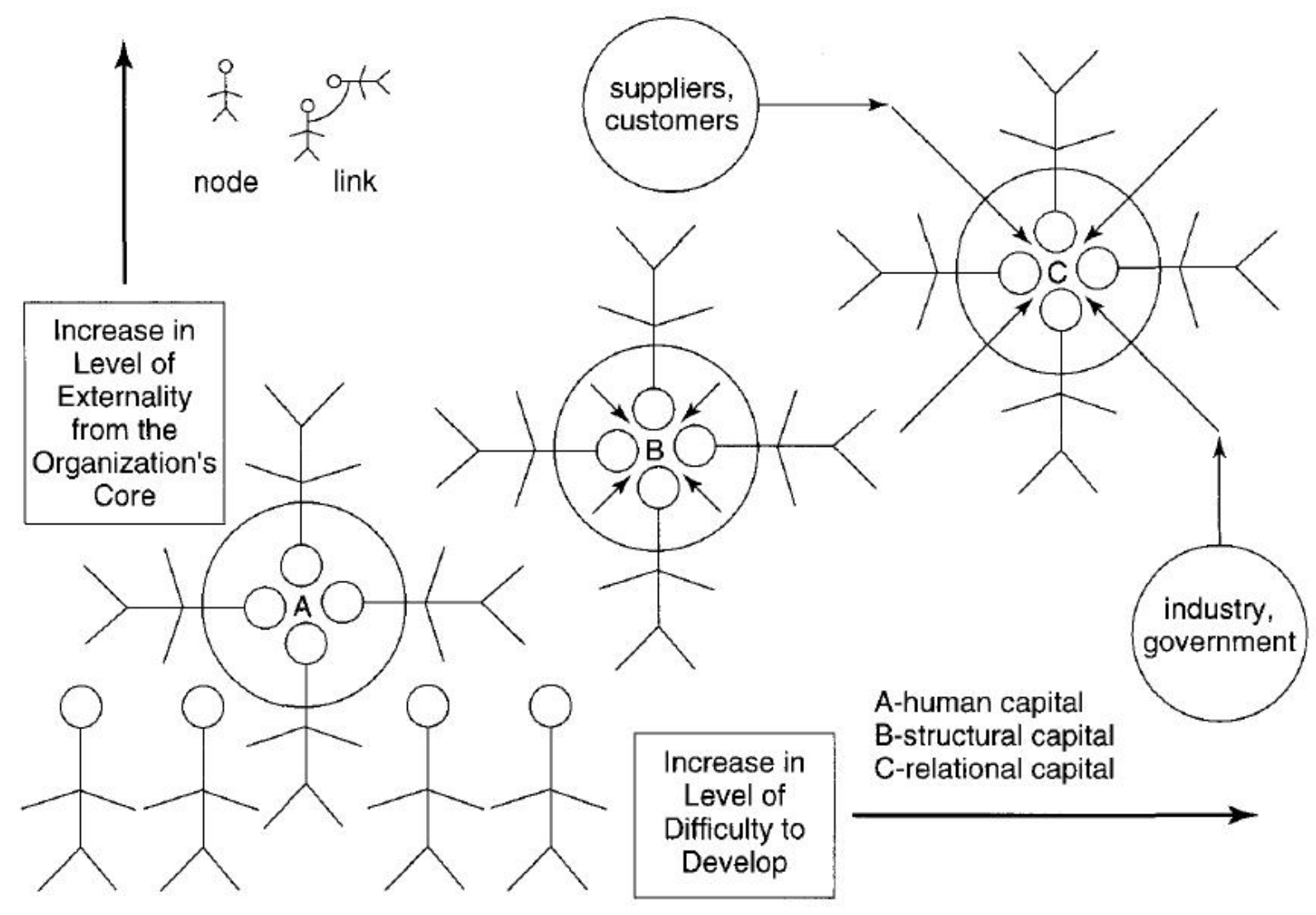

Figure 2. Discriminating intellectual capital subdomains (Source: Bontis, 2002; 631).

\subsection{Structural capital}

Structural capital refers to the learning and knowledge that is enacted in processes (process capital). From an intellectual capital perspective, knowledge management is about the capture, storage, and retrieval of knowledge located either in the heads of employees, in the heads of outside collaborators, or in documents. Capture, storage, and retrieval are brought about through a firm's structural capital, defined by Edvinsson (1997) as "the embodiment, empowerment, and supportive infrastructure of human capital." Structural capital is also where the value added by the nonlinearities of the knowledge creation process is assumed to reside. There are important implications for knowledge managing investment in "soft" assets such as brand names, strategic alliances, and personnel skills. Such thinking leads, for instance, to human capital accounting and the kind of organizational practices made famous by Skandia (e.g., Hedberg 2000). Point B in figure 2 illustrates the structural ties or links of human capital nodes that are required to transform human capital into structural capital. The arrows within structural capital represent the focus of intellectual capital development from the nodes into the organization's core.

Structural capital includes two dimensions: process capital and innovation capital. Edvinsson and Malone (1997) show that process capital supports employees and enhances firm productivity. A learning organization increases knowledge management efficiency and builds 
up a sharing and communicating culture that positively effect on performance (Brentani and Kleinschmidt, 2004). Bontis et al. (2000) empirical study on intellectual capital and firm performance in Malaysia indicates that structural capital positively impacts on firm performance in the service industry but not in the non-service industry. Pena (2002) also mentioned that structural capital influences new business survival and growth. According to these argues, following hypothesis is developed:

H2: Structural capital affects organizational performance positively.

\subsection{Relational capital}

Knowledge that is codified as documents, objects, and intellectual property (intellectual assets); and the reputation and relationships the organization has developed during time with customers and stakeholders (relational capital). Knowledge of market channels and of client and provider relationships, also as a sound understanding of governmental or business association impacts, is that the main theme of relational capital. Relational capital represents the potential a company has attributable to ex-firm intangibles. These intangibles embrace the data embedded in customers, suppliers, the govt., or connected business associations. Point $\mathrm{C}$ in figure 2 a pair of illustrates that relational capital is that the toughest of the three subdomains to develop since it's the foremost external to the organization's core. The arrows represent the data that has to flow from sources external to the organization (i.e., its environment) into the organization's core by method of linked nodes.

Hill and Jones (2001) mentioned that organization stakeholders often provide the organization with important resources. Customers provide income, suppliers provide materials, and distributors prepare sales channels. Firms' strategic partners are advantageous for new product development (Kodama, 2005). Firms should therefore understand and satisfy stakeholder needs to enhance their performance. Many investigations debates that customer collaboration is very important to achieve innovation and economic success. This cooperation improves organizational performance. Schulz (2001) further indicates that common values and trust in a network not only eliminate conflicts, but also enhance communication and harmony between members of networks. These attributes are critical for increasing performance.

\section{H3: relational capital affects organizational performance positively.}

\subsection{Mutual relationship between three categories of intellectual capital}

Bontis et al. (2000) indicated that human capital significantly affects customer capital in all industries. Human capital significantly affects structural capital in non-service industries, while customer capital affects structural capital in both service and non-service industries. Employee abilities also affect a firm's process efficiency and innovation processes. Higher quality employees will be more pleasant and provide more information to customers and business partners. These employees will attract good customers and business partners as a result. In other words, human capital positively affects relational capital. A firm maintaining a good relationship with its customers and business partners enables the employee to discuss business processes or innovations with customers and business partners. In other words, 


\section{Macrothink}

Asian Journal of Finance \& Accounting

ISSN 1946-052X 2013, Vol. 5, No. 1

relational capital positively affects structural capital (Hsu and Fang, 2009). According to this, following hypotheses are developed:

H4: Human capital affects structural capital positively.

H5: Relational capital affects structural capital positively.

H6: Human capital affects relational capital positively.

\subsection{Organizational performance}

Notwithstanding intellectual capital is generally intangible in nature, it is becoming widely accepted as a major corporate strategic asset capable of creating sustainable competitive advantage and exceptional performance (Barney, 1991). Strategy management is bothered with understanding the causes and forces that designate performance variations between organizations. Performance variations between organizations, then, are results of their totally different stocks of knowledge and their differing capabilities in developing and deploying knowledge. Information and competence became the first drivers of competitive advantage in advanced nations (Choo and Bontis, 2002; VII). According to conceptual model shown in figure 3, we developed three hypotheses for indirect paths in model.

H7: Human capital affects organizational performance through structural capital.

H8: Relational capital affects organizational performance through structural capital.

H9: Human capital affects organizational performance through relational capital.

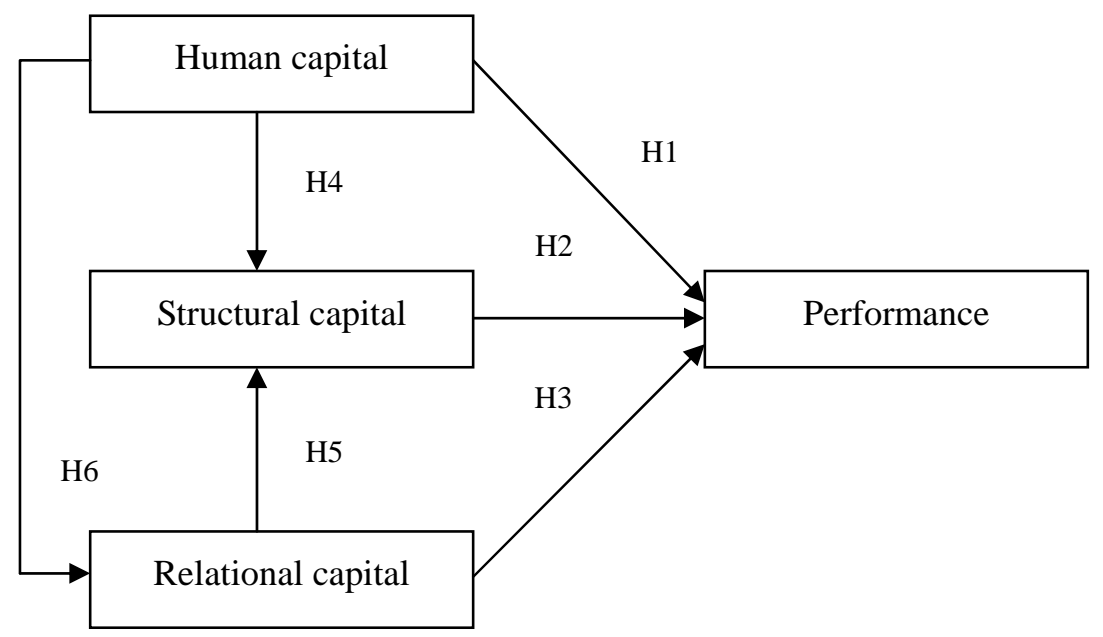

Figure 3. research conceptual model.

\section{Methodology}

\subsection{Sample and data collection}

This study concentrates on accounting and audit institutes of Tehran. Population of study was selected from accountants working in audit organizations because intellectual capital 
accounting is an issue that includes auditing intangible assets of organization. Hence, accountants engage always with this problem to evaluation of this kind of assets. In other hands, for accounting and audit institutes, having skilled and experienced (employees) accountants have been a competitive advantages. Therefore, these institutes typically appreciate excellent human capital (a subsection of intellectual capital as mentioned in literature) for attract and maintain new and old customers. Statistics obtained from Audit Organization of Tehran indicate that 232 organizations are members of Iranian Accounting Association work in Tehran. The questionnaire distributed between accountants working in mentioned-above organizations. From 500 distributed questionnaires came back 406 complete questionnaires that shows $81 \%$ response rate. More than $74 \%$ of participants were male in which $32 \%$ of them have more than 20 years background in auditing. They earn almost 30,000,000 Rials monthly. 91\% of participants had academic degree in Accounting.

\subsection{Measures}

For consistency, all responses were measured using a Likert-type scale, with 1=“strongly disagree," $3=$ ="neutral," and 5="strongly agree.” The questionnaire comprised three parts. The first part describes individuals' demographic data. The second part contained measurements of intellectual capital (including human capital, structural capital, and relational capital); the third part measured organizational performance.

\section{Results}

\subsection{Correlation}

As show in table 1, the high value for correlation between variables belongs to human capital and performance. This shows that intellectual capital could be one of the predictors towards firms' performance. In a knowledge-based economy, it is expected that the knowledge workers (human capital) will increase organisations power to generate competitive advantages (Hazlina and Zubaidah, 2008) which can increase profit of a company. Relationships between relational capital, human capital, and structure capital have relatively good correlation. But, relational capital and performance don't have a suitable correlation. This means that knowledge documented in records and links between organization and its stakeholders in external environment.

Table 1. Correlation value between variables.

\begin{tabular}{|c|c|c|c|c|}
\hline Variables & $\begin{array}{c}\text { Structure } \\
\text { capital }\end{array}$ & $\begin{array}{c}\text { Relation } \\
\text { capital }\end{array}$ & $\begin{array}{c}\text { Human } \\
\text { capital }\end{array}$ & performance \\
\hline Structure capital & 1.00 & & & \\
\hline Relation capital & 0.41 & 1.00 & & \\
\hline Human capital & 0.46 & 0.43 & 1.00 & 1.00 \\
\hline performance & 0.25 & 0.13 & 0.57 & \\
\hline
\end{tabular}




\section{Macrothink}

\subsection{Path analysis}

Goodness of fit statistics for research model shows that the Model is saturated, the Fit is perfect. Minimum Fit Function Chi-Square is $0.0(\mathrm{P}=1.00)$ and Normal Theory Weighted Least Squares Chi-Square is $0.00(\mathrm{P}=1.00)$.

For hypothesis 1, relationship between human capital and performance is accepted $(\mathrm{t}=4.53)$. as shown in correlation results, knowledge and experience in people minds can impact on organization outcome and performance dramatically. Findings can't support hypothesis 2, therefore, there is no link between structural capital and performance. Also, for hypothesis 3 was rejected. Findings show that there is a link between human capital structural capital and relational capital (for $\mathrm{H} 4$ and $\mathrm{H} 5$ ). For indirect paths, human capital can impact on performance through relational capital but not structural capital; because it was not observed any relation between structural capital and performance. This means that structural capital can't play role of mediator within two variables. Finally, structural capital plays a mediator role in impact of relational capital on performance. All results of hypotheses testing were shown in table 2.

Table 2. path analysis results for all hypotheses.

\begin{tabular}{|c|l|c|c|}
\hline $\begin{array}{c}\text { Hypothesis } \\
\text { (path) }\end{array}$ & \multicolumn{1}{|c|}{ Variables } & t-value & $\begin{array}{c}\text { Standard } \\
\text { value }\end{array}$ \\
\hline 1(direct) & Human capital on performance & 4.53 & 0.23 \\
\hline 2(direct) & Structural capital on performance & 0.55 & 0.03 \\
\hline 3(direct) & Relational Capital on performance & 1.51 & 0.08 \\
\hline 4(direct) & Human capital on Structural capital & 2.88 & 0.14 \\
\hline 5(direct) & Relational Capital on Structural capital & 4.18 & 0.21 \\
\hline 6(direct) & Human capital on Relational Capital & 1.38 & 0.07 \\
\hline 7(indirect) & $\begin{array}{l}\text { Human capital on performance through Structural } \\
\text { capital }\end{array}$ & 3.07 & 0.05 \\
\hline 8(indirect) & $\begin{array}{l}\text { Relational Capital on performance through } \\
\text { Structural capital }\end{array}$ & $\begin{array}{l}\text { Human capital on performance through Relational } \\
\text { Capital }\end{array}$ & 2.74 \\
\hline 9(indirect) & \multicolumn{1}{|c|}{0.04} \\
\hline
\end{tabular}




\section{Conclusion}

Scholars, enterprises, and governments take into account intellectual capital from in practical applications and further discussion recently. In this study, we attempt to investigate relationship between intellectual capital dimensions and organisation performance. As debated in previous section, no relation was observed between structural capital and performance, and between relational capital and performance. Manager should consider processes in which knowledge created and learning taken place. Our finding can't confirm Bontis et al. (2000) findings that observed there is a positive relationship between structural capital and performance in service industry. Structural capital marginally negatively affects performance, indicating. For increase structural capital impact, investments in information technology and innovation help a firm utilize and maximize knowledge creation to improve its organizational performance. Relational capital can be explained by the relationship of customers and partners, where sustaining a good relationship is fundamental. Hence, managers can maintain continuous linkage with their stakeholders as customers, government's departments, market, and so on. Human capital significantly impacts organizational performance, meaning that good quality human resources form a key element in knowledge-intensive industries because knowledgeable workers generate excellent organizational performance. A firm emphasizing human capital gives its employees the chance to contribute increasing organisation performance.

\section{References}

Barney, J.B. (1991). Firm resources and sustainable competitive advantage. Journal of Management, 17(1), 99-120. http://dx.doi.org/10.1177/014920639101700108

Bontis, N. (2002). Managing Organizational Knowledge by Diagnosing Intellectual Capital: Framing and Advancing the State of the, in (ed.) Choo, C.W., Bontis, N. The Strategic Management of Intellectual Capital and Organizational Knowledge, Oxford, NY.

Bontis, N., Keow, W.C.C., \& Richardson, S. (2000). Intellectual capital and business performance in Malaysian industries. J. Intellect. Cap. 1(1), 85-100. http://dx.doi.org/10.1108/14691930010324188

Chen, M.C., Cheng, S.J., \& Hwang, Y. (2005). An empirical investigation of the relationship between intellectual capital and firms' market value and financial performance. Journal of Intellectual Capital, 6(2), 159-176. http://dx.doi.org/10.1108/14691930510592771

Dakhli, M. De, \& Clercq, D. (2004). Human capital, social capital, and innovation: a multi-country study, Entrep. Reg. Dev. 16(2) 107-128. http://dx.doi.org/10.1080/08985620410001677835

De Brentani, U., \& Kleinschmidt, E.J. (2004). Corporate culture and commitment: impact on performance of international new product development programs, J. Prod. Innov. Manag., 21(5), 309-333. http://dx.doi.org/10.1111/j.0737-6782.2004.00085.x

Edvinsson, L., \& Malone, M. (1997). Intellectual Capital. New York: Harper Business. 
Edvinsson, L., \& Sullivan, P. (1996). Developing a model for managing intellectual capital. European Management Journal, 14(4). http://dx.doi.org/10.1016/0263-2373(96)00022-9

Gazor, H., Koohkan, F., Kiarazm, A., \& Nazari Ameleh, K., (2012). Influential factors on knowledge sharing in banking industry. Management Science Letters, 2(6), 2215-2224. http://dx.doi.org/10.5267/j.msl.2012.05.024

ge, H. (1996). Tacit knowledge: the key to the strategic alignment of intellectual capital. Strategy and Leadership, 24(2), 10-14. http://dx.doi.org/10.1108/eb054547

Guthrie, J. (2001). The management, measurement and reporting of intellectual capital. $J$. Intellect. Cap., 2 (1) 27-41. http://dx.doi.org/10.1108/14691930110380473

Hazlina, H., \& Zubaidah, Z.A. (2008). Relationship between intellectual capital and firms' performance: evidence from public listed companies in Malaysia. Proceeding International Accounting Business Conference in Johor Bahru, Malaysia.

Hedberg, B. (2000). The new organizations: managing multiple arenas for knowledge creation, in C. Despres and D. Chauvel (eds.), Knowledge Horizons: The Present and the Promise of Knowledge Management, pp. 269-286. New York: Butterworth-Heinemann. http://dx.doi.org/10.1016/B978-0-7506-7247-4.50016-1

Hill, C.W.L., \& Jones, G.R. (2001). Strategic Management: an Integrated Approach. Houghton Mifflin, Boston.

Hurwitz, J. Lines, S. Montgomery, \& B. Schmidt, J. (2002). The linkage between management practices, intangibles performance and stock returns. J. Intellect. Cap. 3(1), 51-61. http://dx.doi.org/10.1108/14691930210412845

Kaplan, R.S., \& Norton, D.P. (1992). The balanced scorecard- measures that drive performance. Harvard Bus. Rev., 71-79 (January/February).

Kodama, M. (2005). Knowledge creation through networked strategic communities. Long Range Plan, 38(1), 27-49. http://dx.doi.org/10.1016/j.lrp.2004.11.011

Lynn, B. (1998). Performance evaluation in the new economy. International Journal of Technology Management, 16(l/2/3),162-176.

McElroy, M.W. (2002). Social innovation capital. J. Intellect. Cap., 3(1) 30-39. http://dx.doi.org/10.1108/14691930210412827

Nonaka, I., \& Takeuchi, H. (1995). The Knowledge Creating Company. Oxford University Press, New York.

Rhyne, L.C., Teagarden, M.B., \& Van den Panhuyzen, W. (2002). Technology-based competitive strategies - the relationship of culture dimension to new product innovation. $J$. High Technol. Managem. Res., 13 (2) http://dx.doi.org/10.1016/S1047-8310(02)00047-0 


\section{Macrothink}

Asian Journal of Finance \& Accounting ISSN 1946-052X 2013, Vol. 5, No. 1

Roos, J., Roos, G., Dragonetti, N., \& Edvinsson, L. (1998). Intellectual Capital: Navigating in the New Business Landscape. New York: New York University Press.

Roos, J., Roos, R., Edvinnsson, L., \& Dragonetti, N. (1998). Intellectual Capital: Navigating in the New Business Landscape. New York University Press, New York.

Schulz, M. (2001). The uncertain relevance of newness: organizational learning and knowledge flow. Acad. Manage. J., 44(4), 661-681. http://dx.doi.org/10.2307/3069409

Stewart, G., III. (1991). The Quest for Value. New York: HarperCollins.

Stewart, G., III. (1994). EVA ${ }^{\mathrm{TM}}$ : fact and fantasy. Journal of Applied Corporate Finance, 7(2), 71-84. http://dx.doi.org/10.1111/j.1745-6622.1994.tb00406.x

Stewart, T. (1997). Intellectual Capital: The New Wealth of Organizations. New York: Doubleday.

Stewart, T.A. (1997). Intellectual Capital: the New Wealth of Organizations. Doubleday Dell Publishing Group, New York.

Sullivan, P., \& Edvinsson, L. (1996). A model for managing intellectual capital. in R. Parr and P. Sullivan (eds.), Technology Licensing. New York: Wiley.

Sveiby, K.E. (1997). The New Organizational Wealth: Managing and Measuring Knowledge- Based Assets. New York: Berrett-Koehler 